ISSN: 2302-8556

E-Jurnal Akuntansi Universitas Udayana

Vol.24.2.Agustus (2018): 1105-1134

DOI: https://doi.org/10.24843/EJA.2018.v24.i02.p11

\title{
Analisis TAM Terhadap Sikap Penggunaan Sistem Informasi Akuntansi Penggajian di PT Garuda Indonesia Station DPS
}

\author{
Putu Nanda Christy Dio Vidantika ${ }^{1}$ \\ I Made Pande Dwiana Putra ${ }^{2}$
}

\author{
${ }^{1}$ Fakultas Ekonomi dan Bisnis Universitas Udayana (Unud), Bali, Indonesia \\ email: satsukichunuchiwa@ gmail.com /telp: +62 81547132732 \\ ${ }^{2}$ Fakultas Ekonomi dan Bisnis Universitas Udayana (Unud), Bali, Indonesia
}

\begin{abstract}
ABSTRAK
Sistem informasi akuntansi (SIA) yang diimplementasikan dengan baik dapat menghasilkan informasi keuangan yang andal untuk perusahaan. Penggunaan teknologi SIA dalam proses bisnis penggajian sebaiknya mempertimbangkan kegunaan dan kemudahan penggunanya sehingga sistem menjadi efektif. Tujuan penelitian ini adalah untuk melihat pengaruh dari perceived usefulness dan perceived ease of use terhadap attitude towards use yang menjadi indikator penerimaan teknologi SIA penggajian. Penelitian dilakukan pada PT Garuda Indonesia Station DPS. Jumlah sampel penelitian sebanyak 68 orang dipilih dengan metode nonprobability sampling. Pengumpulan data dilakukan dengan metode survei, observasi, wawancara dan studi kepustakaan. Teknik analisis yang digunakan adalah analisis regresi linear berganda. Berdasarkan hasil analisis ditemukan bahwa perceived usefulness dan perceived ease of use berpengaruh positif terhadap attitude towards use teknologi SIA atas proses bisnis penggajian. Hal ini menunjukkan bahwa semakin teknologi SIA penggajian bermanfaat dan mudah digunakan oleh karyawan, maka sikap penerimaannya terhadap teknologi tersebut akan meningkat.
\end{abstract}

Kata kunci: Attitude towards use, perceived usefulness, perceived ease of use, SIA

\begin{abstract}
A well-implemented accounting information system (AIS) can provide a reliable financial information for company. The use of technology on AIS for the payroll business process should consider usefulness and easiness of its users so the system becomes effective. This study was aimed to examine the effect of perceived usefulness (PU) and perceived ease of use (PEOU) toward attitude towards use (ATU) as an acceptance indicator of technology. The research was conducted at PT Garuda Indonesia Station DPS. The samples as many as 68 peoples were selected by nonprobability sampling method. The data were collected by using survey, observation, interview, and literature study. The analysis technique used the multiple linear regression analysis. The result showed that PU and PEOU positively influence ATU of technology on AIS for payroll business process. This showed that the more useful and easy technology of SIA for payroll is, the acceptance of technology will be better.
\end{abstract}

Keywords: attitude towards use, perceived usefulness, perceived ease of use, AIS 


\section{PENDAHULUAN}

Perusahaan dengan sistem informasi (SI) yang baik akan mampu mendeteksi secara efektif ancaman dalam lingkungan bisnis, dimana deteksi efektif dapat membantu pemberian tanggapan strategis. SI juga memberi manfaat dalam bidang akuntansi. Sistem informasi akuntansi (SIA) adalah proses pengumpulan, pengelompokan, pengolahan dan penyajian data transaksi yang nantinya akan menjadi laporan keuangan bagi pihak manajemen (Kezia, 2016). SIA adalah bagian penting dalam peningkatan efisiensi organisasi serta mendukung daya saing melalui penyediaan baik informasi keuangan maupun akuntansi bagi manajemen (Alsarayreh et al., 2011). SIA adalah salah satu faktor penting pencapaian kinerja yang lebih besar, terutama dalam proses pengambilan keputusan (Aleqab dan Adel, 2013). Penerapan SIA merupakan investasi penting untuk perusahaan (Raupeliene, 2003).

Investasi di bidang teknologi informasi umumnya dimaksudkan untuk memberikan kontribusi terhadap kinerja individual anggota organisasi dan instansi (Kristiani, 2012). Teknologi informasi merupakan teknologi yang digunakan dalam proses mengelola hingga menyampaikan informasi. American Institute of Certified Public Accountants (AICPA) telah membuat Certified Information Technology Professional (CITP), yang menunjukkan bahwa teknologi dalam SIA penting untuk digunakan. Penggunaan teknologi SI dapat meningkatkan daya saing agar perusahaan tidak tersisih dalam persaingan (Kustono, 2011). Salah satu topik sensitif yang melibatkan berbagai pelaku bisnis sekaligus pembuat keputusan adalah sistem 
ISSN: 2302-8556

E-Jurnal Akuntansi Universitas Udayana Vol.24.2.Agustus (2018): 1105-1134

penggajian karyawan. Proses bisnis penggajian adalah rangkaian aktivitas bisnis berulang dan operasional pemrosesan data terkait yang berhubungan dengan cara yang efektif dalam mengelola pegawai (Romney dan Steinbart, 2005:184). Folorunsho (2012) dalam Kezia dan Jantje (2016) menyebutkan bahwa karyawan membentuk tulang punggung organisasi. Mereka memberikan layanan dan sebagai imbalannya mendapatkan kompensasi. Biaya memberikan manfaat kepada karyawan sebagai imbalan untuk layanan yang ditawarkannya disebut biaya gaji. Satu komponen utama dari biaya gaji dalam setiap organisasi adalah upah dan gaji dibayar kepada karyawan.

Biaya gaji merupakan biaya yang penting dan dapat menimbulkan risiko terjadinya kesalahan maupun kecurangan. SIA penggajian yang diimplementasikan dengan baik dapat menghasilkan informasi keuangan yang andal karena kerangka kerjanya saling berhubungan. Penggunaan teknologi SIA dalam proses bisnis penggajian sebaiknya mempertimbangkan kegunaan dan kemudahan penggunanya, sehingga sistem menjadi efektif. Faktor pengguna mempunyai pengaruh yang besar dalam menentukan kesuksesan penerapan sistem (Santoso, 2012).

Nasution (2004) mengungkap bahwa penting untuk memperhatikan aspek perilaku saat mengadopsi teknologi informasi, karena interaksi pengguna dengan komputer merupakan hasil pengaruh persepsi, sikap, dan afeksi sebagai aspek keperilakuan individu sebagai pengguna. Penelitian menunjukkan bahwa penyebab kegagalan teknologi SIA adalah lebih pada aspek keperilakuannya (Hartono, 2007). Disebutkan oleh Venkatesh (2000) bahwa meskipun penerimaan teknologi SIA di 
tempat kerja merupakan hal yang rumit dan sulit dipahami, hal tersebut tetaplah sebuah fenomena penting.

Penelitian ini menggunakan konsep model berketerimaan teknologi (Technology Acceptance Model-TAM) yang dilandasi teori tindakan beralasan (Theory of Reasoned Action-TRA). Disebutkan oleh Fishbein dan Ajzen (1975) dalam Sherina (2014), TRA mengasumsikan bahwa perilaku didasarkan oleh niat individu untuk terlibat dalam tindakan tertentu. Atitude towards use menunjukkan sikap individu terhadap objek tertentu adalah fungsi dari keyakinannya tentang objek tersebut dan merupakan sebuah respon penilaian evaluatif terkait keyakinannya.

Sementara itu, TAM menganggap pengguna sistem cenderung menggunakan sistem apabila sistem mudah digunakan dan bermanfaat baginya. Konsep TAM yang dikembangkan oleh Davis menawarkan penjelasan yang kuat untuk menguji perilaku penerimaan dan penggunaan sistem informasi (Handayani, 2005). Tujuan dikembangkannya konsep TAM adalah untuk dapat menggambarkan perilaku penggunaan teknologi (Kurniawan, 2013). Kurniawan juga menyebutkan bahwa perceived usefulness adalah tingkat dimana seseorang percaya bahwa menggunakan sistem dapat meningkatkan kinerjanya dan perceived ease of use adalah tingkat dimana seseorang percaya bahwa menggunakan sistem tidak diperlukan usaha apapun.

Menurut Kumar (1990) dalam McCoy (2002), adanya perkembangan dalam dunia bisnis menimbulkan kebutuhan untuk melanjutkan studi terkait penggunaan teknologi informasi. Studi terkait penggunaan teknologi informasi yang dilakukan oleh 
ISSN: 2302-8556

E-Jurnal Akuntansi Universitas Udayana Vol.24.2.Agustus (2018): 1105-1134

David Kurniawan pada tahun 2013 menyebutkan bahwa variabel perceived usefulness dan perceived ease of use layanan mobile banking BCA berpengaruh positif terhadap attitude towards use. Fuad Budiman dan Fefri Indra (2013) dalam penelitiannya yang berjudul "Pendekatan Technology Acceptance Model dalam Kesuksesan Implementasi Sistem Informasi Manajemen Daerah" memperoleh hasil serupa bahwa perceived usefulness dan perceived ease of use penggunaan aplikasi Sistem Informasi Manajemen Daerah (SIMDA) berpengaruh positif terhadap attitude towards use aplikasi SIMDA di Satuan Kerja Perangkat Daerah (SKPD) Kabupaten Pasaman. Sementara itu, penelitian terhadap penggunaan teknologi informasi di SKPD Kabupaten Sragen yang dilakukan Budi Santoso (2012) memperoleh kesimpulan berbeda, bahwa perceived usefulness tidak berpengaruh terhadap attitude towards use sedangkan perceived ease of use berpengaruh terhadap attitude towards use.

Penerimaan teknologi sistem informasi akuntansi penggajian juga menjadi hal kritis dalam perusahaan penerbangan PT Garuda Indonesia (Persero) Tbk. Permintaan terhadap jasa industri penerbangan yang semakin meningkat menyebabkan Garuda Indonesia terus mengembangkan jaringan penerbangan dan layanannya. Peningkatan jumlah penerbangan tersebut sejalan dengan peningkatan jumlah tenaga kerja. Garuda Indonesia Station Bandar Udara Internasional Ngurah Rai (DPS) meningkatkan kualitas layanan pre-flight-nya dengan mengoptimalkan kinerja karyawan bagian departure frontliner. Dengan kompleksitas dan beban kerja yang tinggi dari departure frontliner, perusahaan memberikan balas jasa berupa gaji. Gaji harus diberikan secara 
rutin dan tepat waktu dalam setiap periode pembayaran. Intensitas karyawan dan kegiatan yang sifatnya repetitif tersebut menyebabkan fungsi penggajian menjadi salah satu sistem pertama yang diotomatisasi di beberapa organisasi. Bahkan faktanya, perangkat lunak untuk fungsi penggajian merupakan yang pertama dikembangkan dan dipasarkan secara komersial (Gelinas et al, 1990:428). Berdasarkan hal tersebut, keberadaan suatu teknologi SIA dalam proses bisnis penggajian menjadi penting. Perubahan sistem penggajian karyawan bagian departure frontliner di PT Garuda Indonesia Station DPS dari sistem manual ke sistem penggajian berbasis teknologi menimbulkan reaksi yang beranekaragam dari penggunanya. Ada yang menerima dan ada pula yang memberi reaksi penolakan. Namun, teknologi SIA penggajian tersebut sebaiknya diterima oleh seluruh karyawan sehingga investasi besar untuk pengadaannya akan diimbangi oleh penggunaan yang baik pula.

Penggunaan teknologi SIA dalam proses penggajian karyawan bagian departure frontliner PT Garuda Indonesia station DPS juga dapat membantu proses penggajian menjadi lebih mudah dan efektif. Karyawan bagian departure frontliner sebagai salah satu pihak yang terlibat dalam proses penggajian, terutama selama proses pencatatan waktu, harus merasakan manfaat dan kemudahan dari penggunaan teknologi SIA penggajian. Dengan pemanfaatan teknologi SIA penggajian, beberapa masalah dapat diminimalisir, seperti masalah keterlambatan pendistribusian gaji, kesalahan pencatatan absensi karyawan, kesalahan penghitungan gaji, tunjangan serta 
ISSN: 2302-8556

E-Jurnal Akuntansi Universitas Udayana

Vol.24.2.Agustus (2018): 1105-1134

potongan, kehilangan data karyawan, serta masalah lain yang mungkin timbul selama proses penggajian berlangsung.

Berdasarkan pada pentingnya penerimaan teknologi sistem informasi dan adanya perbedaan dalam hasil penelitian-penelitian sebelumnya terkait pengaruh variabel perceived usefulness serta perceived ease of use terhadap variabel attitude towards use, maka penelitian ini dilakukan untuk melihat pengaruh dari perceived usefulness dan perceived ease of use terhadap attitude towards use yang menjadi indikator penerimaan teknologi SIA atas proses bisnis penggajian karyawan bagian departure frontliner di PT Garuda Indonesia Station DPS. Melalui analisis dalam faktor-faktor tersebut diharapkan dapat dipahami faktor determinan penerimaan teknologi SIA dalam proses bisnis penggajian, sehingga hasilnya dapat dijadikan masukan bagi berbagai pihak yang membutuhkan. Berdasarkan uraian tersebut, penelitian mengambil judul analisis technology acceptance model terhadap sikap penggunaan sistem informasi akuntansi atas proses bisnis penggajian di PT Garuda Indonesia Station DPS.

Berdasarkan latar belakang tersebut, rumusan masalah dalam penelitian ini dibagi menjadi apakah perceived usefulness dan perceived ease of use berpengaruh terhadap attitude towards use teknologi SIA atas proses bisnis penggajian karyawan bagian departure frontliner di PT Garuda Indonesia Station DPS ?

Penelitian ini dapat digunakan sebagai pendukung teoritis atau menambah khasanah ilmu pengetahuan mengenai pengaruh perceived usefulness dan perceived 
ease of use terhadap attitude towards use teknologi SIA atas proses bisnis penggajian karyawan. Sementara itu, hasil penelitian ini diharapkan dapat memberi manfaat praktis dalam memberi sumbangan pemikiran bagi perusahaan dan pihak yang berkepentingan untuk pengambilan kebijakan terkait pengadaan dan penggunaan teknologi SIA atas proses bisnis penggajian karyawan, sehingga kebijakan pengadaan teknologi dapat diterima secara maksimal.

Landasan teori dan konsep yang digunakan dalam penelitian ini diawali dengan teori TAM sebagai grand theory yang menyebutkan bahwa kedua variabel model TAM yaitu kemanfaataan (usefulness) dan kemudahan penggunaan (ease of use) dapat menjelaskan aspek keprilakuan pengguna (Davis et.al., 1989). Teori TAM dilandasi oleh teori TRA yang dikembangkan oleh Fishbein dan Ajzen. TRA merupakan teori dinamika terbentuknya sikap dan perilaku. Secara keseluruhan perilaku individu dijelaskan dengan mempertimbangkan faktor kepercayaannya (Hartono, 2007). Selanjutnya, attitude towards use menurut Aakers dan Myers (1997) dalam Armanda (2015) adalah sikap suka atau sikap tidak suka dalam penggunaan produk tertentu. Sikap tersebut dapat memprediksi niat seseorang untuk menggunakan atau tidak menggunakan suatu produk. Sikap terhadap penggunaan teknologi didefinisikan sebagai evaluasi pemakai tentang ketertarikannya menggunakan teknologi, Arif (2008) dalam Suseno (2009). Kemudian menurut Davis, F.D. (1989), perceived usefulness ialah suatu tingkatan dimana individu percaya bahwa penggunaan subyek tertentu akan dapat meningkatkan prestasi kerjanya. Davis, F.D. (1989) juga mendefinisikan 
ISSN: 2302-8556

E-Jurnal Akuntansi Universitas Udayana Vol.24.2.Agustus (2018): 1105-1134

perceived ease of use sebagai suatu tingkatan dimana seseorang percaya bahwa penggunaan sistem tertentu dapat mengurangi usaha seseorang dalam mengerjakan sesuatu. Teori lainnya yang digunakan dalam penelitian ini adalah teori tentang SIA, dimana menurut Bodnar dan Hopwood (2006:3) SIA merupakan kumpulan sumber daya, seperti manusia dan peralatan, yang dirancang untuk mengubah data keuangan dan data lainnya ke dalam informasi. Penggunaan infrastruktur teknologi informasi perusahaan dapat menjadi sumber bisnis utama dan sumber kunci untuk keunggulan bersaing berkelanjutan (Keen, 1991 dan McKeney, 1995 dalam Sumistar (2011). Teori terkait proses bisnis dikemukakan oleh Romney dan Steinbart (2005:7) dimana proses bisnis dapat dikelompokkan ke dalam lima siklus, yaitu siklus pendapatan (revenue cycle), siklus pengeluaran (expenditure cycle), siklus produksi atau konversi (production or conversion cycle), siklus SDM atau penggajian (human resources/payroll cycle), dan siklus pembiayaan (financing cycle). Penelitian ini berfokus pada siklus SDM yang lebih lanjutnya disebutkan oleh Mulyadi (2014:17) bahwa sistem akuntansi gaji dirancang untuk menangani transaksi perhitungan dan pembayaran gaji karyawan. Terakhir, sebagai teori pendukung, dalam penelitian ini istilah departure frontliner diartikan sebagai sebuah pekerjaan yang bertugas melayani customer secara langsung selama proses keberangkatannya.

Kerangka konseptual merupakan suatu hubungan logis dari landasan teori dan kajian empiris. Kerangka konseptual menunjukkan pengaruh antar variabel dalam penelitian. Penelitian ini bertujuan untuk melihat pengaruh perceived usefulness dan 
perceived ease of use terhadap attitude towards use sebagai indikator penerimaan teknologi SIA penggajian karyawan bagian departure frontliner di PT Garuda Indonesia Station DPS. Secara sistematis, kerangka konseptual yang digunakan pada penelitian ini dapat dilihat pada Gambar 1.

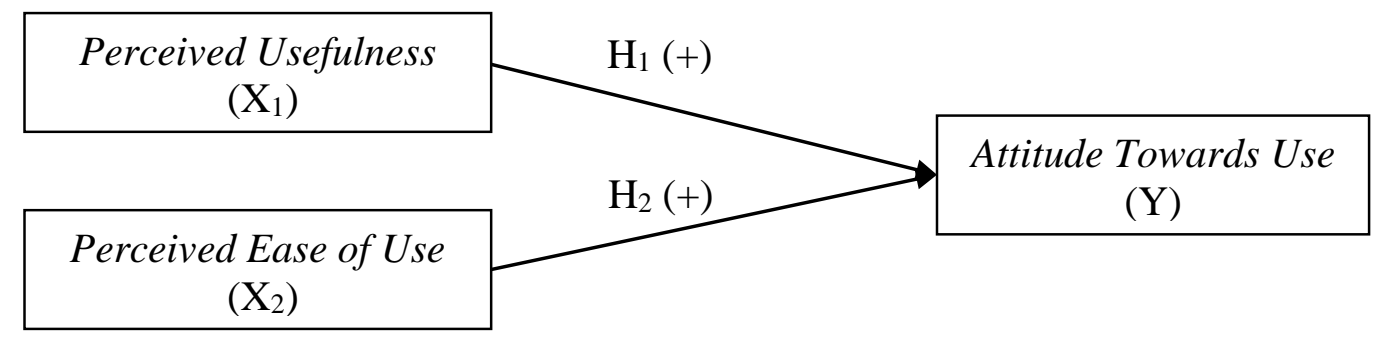

\section{Gambar 1. Kerangka Konseptual}

Davis, F.D (1989) selanjutnya mendefinisikan perceived usefulness sebagai sebuah tingkatan dimana individu percaya bahwa penggunaan subyek tertentu dapat meningkatkan prestasi kerjanya. Dengan kata lain, kebermanfaatan dari penggunaan komputer dapat meningkatkan kinerja dan prestasi kerja penggunanya. Menurut teori TAM, terdapat hubungan antara perceived usefulness dengan attitude towards use, dimana persepsi dari pengguna dapat menentukan sikapnya dalam proses penerimaan teknologi informasi. Thompson (1991) menyebutkan bahwa individu akan menggunakan sistem jika individu tersebut mengetahui manfaat atau kegunaan positif atas penggunaanya. Perceived usefulness akan berpengaruh langsung terhadap attitude towards use teknologi sistem informasi akuntansi penggajian karyawan bagian departure frontliner di PT Garuda Indonesia Station DPS. Perceived usefulness akan berpengaruh langsung terhadap perilaku individual untuk menggunakan teknologi 
ISSN: 2302-8556

E-Jurnal Akuntansi Universitas Udayana Vol.24.2.Agustus (2018): 1105-1134

informasi karena jika pengguna merasakan manfaat dari suatu teknologi SIA, maka sikapnya akan menunjukkan sikap penerimaan. Hal ini didukung dengan hasil penelitian dari Davis (1989), Szajna (1994), Kurniawan (2013), Fuad Budiman dan Fefri Indra (2013), serta penelitian Amadeus (2016) yang memperoleh hasil bahwa perceived usefulness berpengaruh positif terhadap attitude towards use. Berdasarkan penjelasan tersebut dapat dikembangkan hipotesis penelitian sebagai berikut :

$\mathrm{H}_{1} \quad$ : Perceived Usefulness berpengaruh positif terhadap Attitude Towards Use Teknologi Sistem Informasi Akuntansi atas Proses Bisnis Penggajian

Davis, F.D (1989) mendefinisikan perceived ease of use sebagai tingkatan dimana seseorang percaya bahwa penggunaan sistem tertentu dapat mengurangi usahanya dalam mengerjakan sesuatu. Berdasarkan teori TAM, terdapat hubungan antara perceived ease of use dengan attitude towards use, dimana attitude towards use dapat dipengaruhi oleh perceived ease of use. Sistem yang mudah digunakan akan terus dipakai oleh perusahaan. Sistem dengan intensitas penggunaan lebih banyak menunjukan bahwa sistem itu lebih dikenal dan lebih mudah dioperasikan oleh penggunanya. Apabila teknologi SIA mudah digunakan oleh penggunanya, otomatis seseorang akan lebih memilih terus menggunakan teknologi tersebut. Pernyataan tersebut didukung dengan penelitian Davis (1989), Szajna (1994), Budi Santoso (2012), David Kurniawan (2013), Fuad Budiman dan Fefri Indra (2013), serta Amadeus (2016) dengan hasil penelitian yang menyebutkan bahwa variabel perceived 
ease of use berpengaruh positif terhadap variabel attitude towards use. Berdasarkan penjelasan tersebut dapat dikembangkan hipotesis penelitian sebagai berikut :

$\mathrm{H}_{2} \quad$ : Perceived Ease of Use berpengaruh positif terhadap Attitude Towards Use Teknologi Sistem Informasi Akuntansi atas Proses Bisnis Penggajian.

\section{METODE PENELITIAN}

Pendekatan yang digunakan untuk mendapatkan jawaban masalah serta tujuan penelitian dalam penelitian ini adalah pendekatan kuantitatif yang berbentuk asosiatif, dimana pendekatan ini bertujuan untuk mengetahui hubungan antara dua variabel atau lebih (Rahyuda dkk, 2004:17). Penelitian dilakukan di PT Garuda Indonesia Station DPS yang berlokasi di terminal keberangkatan domestik dan internasional Bandar Udara Internasional I Gusti Ngurah Rai dengan alamat di Jalan Raya Gusti Ngurah Rai, Kuta, Kabupaten Badung, Bali. Adapun objek dalam penelitian ini adalah attitude towards use teknologi SIA atas proses bisnis penggajian karyawan bagian departure frontliner di PT Garuda Indonesia station DPS yang dijelaskan dengan variabel perceived usefulness dan variabel perceived ease of use.

Variabel terikat (Y) penelitian adalah attitude towards use teknologi SIA atas proses bisnis penggajian karyawan bagian departure frontliner di PT Garuda Indonesia Station DPS yang menurut Fishbein dan Ajzen (1975) dioperasionalkan dengan 5 indikator yaitu, memudahkan proses, mempercepat proses, menyenangkan untuk digunakan, nyaman untuk digunakan, dan menguntungkan untuk digunakan. 
ISSN: 2302-8556

E-Jurnal Akuntansi Universitas Udayana Vol.24.2.Agustus (2018): 1105-1134

Variabel bebas $(\mathrm{X})$ penelitian ini antara lain perceived usefulness sebagai $\mathrm{X}_{1}$ dan perceived ease of use sebagai $\mathrm{X}_{2}$. Perceived usefulness dalam penelitian ini diukur dengan lima indikator sesuai dengan pernyataan Chin dan Todd (1995) dalam Nasution (2004), meliputi memudahkan pekerjaan, berguna, meningkatkan produktifitas, bekerja lebih efektif, dan meningkatkan kinerja. Sementara itu, perceived ease of use dalam penelitian ini dioperasionalkan dengan empat indikator sesuai dengan pernyataan Davis (1989), yakni mudah dipelajari, mudah digunakan, menambah keterampilan pengguna, dan mudah dioperasikan. Dalam penelitian ini, skala pengukuran yang digunakan adalah skala likert 5 poin.

Berdasarkan jenis data, data yang digunakan dalam penelitian ini antara lain data kualitatif berupa informasi yang berkaitan dengan gambaran umum PT Garuda Indonesia, dan penjelasan penerapan SIA dalam proses bisnis penggajian karyawan bagian departure frontliner pada PT Garuda Indonesia Station DPS, serta data kuantitatif berupa data skor jawaban kuisioner dari responden.

Penelitian ini menggunakan sumber data primer dan sekunder. Sumber data primer dikumpulkan pertama kali oleh peneliti untuk tujuan penelitian, dimana data primer pada penelitian ini berupa hasil kuisioner atau jawaban dari responden. Sementara pengumpulan data sekunder dilakukan oleh orang lain dan peneliti hanya menggunakan data yang telah tersedia tersebut. Data sekunder pada penelitian ini adalah struktur organisasi, data jumlah karyawan, dan gambaran umum PT Garuda Indonesia Station DPS. 
Populasi dalam penelitian ini adalah karyawan bagian departure frontliner PT Garuda Indonesia Station DPS di terminal keberangkatan domestik dan internasional yang berjumlah sebanyak 188 orang. Metode pengambilan sampel yang digunakan adalah non probability sampling dengan teknik purposive sampling, yaitu teknik penentuan sampel dengan kriteria tertentu (Ikhsan, 2008:117). Adapun kriteria sampel dalam penelitian ini meliputi karyawan bagian departure frontliner pada PT Garuda Indonesia Station DPS yang bertugas melayani High Value Customer (HVC), masih bekerja pada tahun 2017, dan merupakan karyawan outsourcing yang menggunakan suatu pilihan pemrosesan yaitu organisasi tenaga kerja atau Professional Employer Organization-PEO (bukan merupakan pegawai tetap). Setelah populasi dipilih berdasarkan kriteria, diperoleh sampel penelitian sejumlah 68 orang.

Metode pengumpulan data adalah bagian instrumen pengumpulan data yang menentukan berhasil atau tidaknya suatu penelitian (Bungin, 2005:133). Metode pengumpulan data dalam penelitian ini antara lain yaitu metode survei dengan teknik kuisioner, observasi, wawancara, dan studi kepustakaan.

Teknik analisis data yang digunakan dalam penelitian ini adalah analisis regresi linear berganda yang diolah dengan bantuan program SPSS. Teknik analisis data diawali dengan pengujian instrumen penelitian, yaitu dengan menguji validitas dan reabilitas instrumen. Selanjutnya dilakukan analisis statistik deskriptif, yang dilanjutkan dengan pengujian asumsi klasik meliputi uji normalitas, uji multikolinearitas, dan uji heteroskedastisitas. Selanjutnya dilakukan analisis regresi 
linear berganda sekaligus untuk melihat nilai koefisien determinasi $\left(\mathrm{R}^{2}\right)$, menguji kelayakan model (Uji F) dan uji hipotesis (Uji t).

Teknik analisis ini dinyatakan dalam model persamaan sebagai berikut :

$\mathrm{Y}=\alpha+\beta_{1} \mathrm{X}_{1}+\beta_{2} \mathrm{X}_{2}+\varepsilon$

Keterangan :

$\mathrm{Y} \quad=$ attitude towards use teknologi sistem informasi akuntansi atas proses bisnis penggajian

$\alpha \quad=$ konstanta

$\beta_{1}, \beta_{2}=$ koefisien regresi

$\mathrm{X}_{1} \quad=$ perceived usefulness

$\mathrm{X}_{2}=$ perceived ease of use

$\varepsilon \quad=$ kesalahan prediksi (error)

\section{HASIL DAN PEMBAHASAN}

Statistik deskriptif memberikan gambaran atau deskripsi suatu data yang dilihat dari nilai minimum, maksimum, rata-rata, dan simpangan baku. Hasil statistik desktiptif penelitian ini dapat dilihat pada Tabel 1 .

\section{Tabel 1.}

Hasil Statistik Deskriptif

\begin{tabular}{lccccc}
\hline \multicolumn{1}{c}{ Variabel } & N & Min. & Max. & Mean & Std. Deviasi \\
\hline Attitude Towards Use $(Y)$ & 68 & 5 & 25 & 18,07 & 3,794 \\
Perceived Usefulness $\left(\mathrm{X}_{1}\right)$ & 68 & 6 & 25 & 19,96 & 3,325 \\
Perceived Ease of Use $\left(\mathrm{X}_{2}\right)$ & 68 & 9 & 20 & 14,56 & 2,695 \\
\hline Sumber: Data diolah, 2017 & & & & &
\end{tabular}

Berdasarkan Tabel 1, dapat diketahui bahwa jumlah sampel dalam penelitian ini berjumlah 68. Untuk variabel terikat attitude towards use, memiliki nilai maximum sebesar 25 dengan nilai average 18,07. Nilai average tersebut menunjukkan bahwa dalam menjawab kuisioner, responden cenderung setuju dengan masing-masing item 
pernyataan. Hal ini berarti, attitude towards use teknologi SIA penggajian cenderung tinggi. Standar deviasi variabel attitude towards use sebesar 3,794 menunjukkan standar penyimpangan data terhadap nilai rata-ratanya adalah 3,794.

Selanjutnya, variabel perceived usefulness memiliki nilai maximum 25 dengan nilai average 19,96. Nilai average sebesar 19,96 menunjukkan bahwa saat menjawab kuisioner, responden cenderung setuju pada item-item pernyataan, sehingga perceived usefulness dalam penggunaan teknologi SIA penggajian cenderung tinggi. Standar deviasi variabel perceived usefulness adalah sebesar 3,325, hal ini menunjukkan bahwa standar penyimpangan data terhadap nilai rata-ratanya adalah 3,325.

Sementara itu, variabel perceived ease of use, memiliki nilai maximum sebesar 20 dengan nilai average 14,56. Nilai average sebesar 14,56 menunjukkan bahwa dalam menjawab kuisioner, responden penelitian cenderung setuju pada masing-masing item pernyataan. Hal ini berarti responden cenderung percaya bahwa teknologi SIA penggajian mudah untuk digunakan. Standar deviasi variabel perceived ease of use sebesar 2,695 menunjukkan bahwa standar penyimpangan data terhadap average adalah sebesar 2,695.

Uji validitas dilakukan untuk menguji seberapa baik instrumen yang digunakan dalam penelitian dapat mengukur konsep yang seharusnya diukur, dimana suatu instrumen dinyatakan valid apabila nilai r Pearson's correlation terhadap skor total diatas 0,30 (Ghozali, 2013:52). Hasil uji validitas dari instrumen dalam penelitian ini dapat dilihat pada Tabel 2. 
ISSN: 2302-8556

E-Jurnal Akuntansi Universitas Udayana

Vol.24.2.Agustus (2018): 1105-1134

Tabel 2.

Hasil Uji Validitas

\begin{tabular}{llccc}
\hline No. & \multicolumn{1}{c}{ Variabel } & $\begin{array}{c}\text { Kode } \\
\text { Instrumen }\end{array}$ & $\begin{array}{c}\text { Nilai Pearson's } \\
\text { Correlation }\end{array}$ & Keterangan \\
\hline & & ATU1 & 0,786 & Valid \\
1. & Attitude Towards Use & ATU2 & 0,886 & Valid \\
& $(\mathrm{Y})$ & ATU3 & 0,860 & Valid \\
& & ATU4 & 0,812 & Valid \\
& & ATU5 & 0,814 & Valid \\
& & PU1 & 0,712 & Valid \\
2. & Perceived Usefulness & PU2 & 0,732 & Valid \\
& $\left(\mathrm{X}_{1}\right)$ & PU3 & 0,692 & Valid \\
& & PU4 & 0,735 & Valid \\
& & PU5 & 0,797 & Valid \\
3. & Perceived Ease of Use & PEU1 & 0,704 & Valid \\
& $\left(\mathrm{X}_{2}\right)$ & PEU2 & 0,836 & Valid \\
& & PEU3 & 0,873 & Valid \\
\hline
\end{tabular}

Sumber: Data diolah, 2017

Berdasarkan Tabel 2, ditarik kesimpulan bahwa instrumen dalam penelitian ini terdiri dari item-item pertanyaan Attitude Towards Use, Perceived Usefulness, dan Perceived Ease of Use adalah valid karena nilai Pearson's Correlation terhadap skor total untuk setiap pertanyaan nilainya positif dan besarnya diatas 0,30 .

Uji reliabilitas dilakukan untuk mencari tahu sejauh mana konsistensi alat ukur yang digunakan. Instrumen dikatakan reliabel apabila nilai Cronbach's Alpha $\geq 0,70$ (Ghozali, 2013:48). Hasil uji reliabilitas instrumen dalam penelitian ini dapat dilihat pada Tabel 3.

Tabel 3.

Hasil Uji Reliabilitas

\begin{tabular}{llcc}
\hline No. & Variabel & $\begin{array}{c}\text { Nilai } \\
\text { Cronbach's } \text { Alpha }\end{array}$ & Keterangan \\
\hline 1. & Attitude Towards Use (Y) & 0,881 & Reliabel \\
2. & Perceived Usefulness $\left(\mathrm{X}_{1}\right)$ & 0,783 & Reliabel \\
3. & Perceived Ease of Use $\left(\mathrm{X}_{2}\right)$ & 0,832 & Reliabel \\
\hline \multicolumn{2}{l}{ Sumber: Data diolah, 2017}
\end{tabular}


Hasil uji reliabilitas yang terlihat dalam Tabel 3 menunjukkan bahwa nilai Cronbach's Alpha dari masing-masing variabel lebih besar dari 0,70, yang artinya seluruh pertanyaan dalam kuisioner penelitian ini reliabel.

Uji normalitas bertujuan untuk menguji apakah dalam model regresi yang dibuat berdistribusi normal atau tidak. Pengujian normalitas distribusi data dilakukan dengan menggunakan uji Kolmogorov-Smirnov. Data atau residual yang dianalisis disebut berdistribusi normal apabila nilai koefisien Asymp. Sig (2-tailed) lebih besar dari taraf signifikansi (Suyana, 2012:99). Taraf signifikansi atau kritis dalam penelitian ini adalah 5\% atau 0,05. Hasil uji normalitas dapat dilihat pada Tabel 4.

Tabel 4.

Hasil Uji Normalitas

\begin{tabular}{ll}
\hline \multicolumn{1}{c}{ Keterangan } & Unstandardized Residual \\
\hline $\mathrm{N}$ & 68 \\
Kolmogorov-Smirnov $Z$ & 1,114 \\
Asymp. Sig. $(2$-tailed) & 0,167 \\
Sumber: Data diolah, 2017 &
\end{tabular}

Nilai signifikansi sebesar 0,167 , dimana nilai tersebut lebih besar dari taraf kritis penelitian sebesar 0,05 $(0,167>0,05)$. Hal ini menunjukkan bahwa data dalam penelitian ini berdistribusi normal.

Uji multikolinearitas bertujuan untuk menguji apakah pada model regresi ditemukan korelasi antara variabel bebasnya, dimana dalam model regresi seharusnya tidak terjadi korelasi di antara variabel-variabel bebasnya. Model regresi dikatakan bebas masalah multikolinieritas apabila nilai tolerance $\geq 0,10$ atau VIF $\leq 10$. Hasil uji multikolinearitas ditunjukkan dalam Tabel 5 sebagai berikut : 
ISSN: 2302-8556

E-Jurnal Akuntansi Universitas Udayana

Vol.24.2.Agustus (2018): 1105-1134

Tabel 5.

Hasil Uji Multikolinearitas

\begin{tabular}{ccccc}
\hline No. & \multicolumn{1}{c}{ Variabel } & Tolerance & VIF & Keterangan \\
\hline 1. & Perceived Usefulness $\left(\mathrm{X}_{1}\right)$ & 0,478 & 2,090 & Bebas Multikolinearitas \\
2. & Perceived Ease of Use $\left(\mathrm{X}_{2}\right)$ & 0,478 & 2,090 & Bebas Multikolinearitas \\
\hline \multicolumn{5}{l}{ Sumber: Data diolah, 2017 }
\end{tabular}

Berdasarkan Tabel 5, nilai tolerance semua variabel bebas lebih besar dari 0,10

dan nilai VIF semua variabel bebas kurang dari 10. Hal ini berarti bahwa seluruh variabel bebas dalam penelitian ini telah terbebas dari masalah multikolinearitas

Uji heteroskedastisitas bertujuan untuk menguji apakah ditemukan ketidaksamaan varians dari residual pengamatan satu ke pengamatan yang lain dalam sebuah model regresi. Dalam penelitian ini, pengujian heteroskedastisitas dilakukan dengan uji Glejser, dimana jika signifikansi t dari hasil meregresi nilai absolute residual variabel bebas lebih dari 5\%, maka model regresi tidak mengandung heteroskedastisitas. Hasil pengujian heteroskedastisitas dapat dilihat pada Tabel 6.

\section{Tabel 6.}

Hasi Uji Heteroskedastisitas

\begin{tabular}{cccc}
\hline No. & \multicolumn{1}{c}{ Variabel } & Signifikansi & Keterangan \\
\hline 1. & Perceived Usefulness $\left(\mathrm{X}_{1}\right)$ & 0,690 & Bebas Heteroskedastisitas \\
2. & Perceived Ease of Use $\left(\mathrm{X}_{2}\right)$ & 0,469 & Bebas Heteroskedastisitas \\
\multicolumn{2}{l}{ Sumber: Data diolah, 2017}
\end{tabular}

Berdasarkan pada Tabel 6, dapat dilihat nilai signifikansi masing-masing variabel lebih besar dari 0,05. Maka disimpulkan bahwa variabel dalam penelitian ini bebas dari heteroskedastisitas.

Analisis regresi linear berganda digunakan untuk melihat pengaruh perceived usefulness dan perceived ease of use terhadap attitude towards use teknologi SIA atas 
proses bisnis penggajian karyawan bagian departure frontliner di PT Garuda Indonesia Station DPS. Hasil regresi memperlihatkan seberapa besar nilai signifikan variabel bebas berpengaruh terhadap variabel terikatnya. Hasil dari analisis regresi linear berganda ditampilkan dalam Tabel 7 sebagai berikut :

\section{Tabel 7.}

Hasil Analisis Regresi Linear Berganda

\begin{tabular}{lccc}
\hline \multicolumn{1}{c}{ Variabel } & $\boldsymbol{\beta}$ & $\mathbf{t}$ & Signifikansi \\
\hline Constant & 3,293 & 1,437 & 0,156 \\
Perceived Usefulness & 0,437 & 2,750 & 0,008 \\
Perceived Ease of Use & 0,417 & 2,127 & 0,037 \\
\hline
\end{tabular}

Sumber: Data diolah, 2017

Didasarkan pada Tabel 7, disusun persamaan regresi linear berganda yakni :

$$
\mathrm{Y}=3,293+0,437 \mathrm{X}_{1}+0,417 \mathrm{X}_{2}+\varepsilon
$$

Koefisien regresi dari perceived usefulness $\left(\beta_{1}\right)$ 0,437 menunjukkan bahwa variabel perceived usefulness memiliki hubungan positif pada variabel attitude towards use teknologi SIA atas proses bisnis penggajian karyawan. Hal ini berarti, apabila perceived usefulness meningkat, maka attitude towards use teknologi SIA atas proses bisnis penggajian karyawan bagian departure frontliner di PT Garuda Indonesia Station DPS akan meningkat. Begitu pula dengan koefisien regresi dari perceived ease of use $\left(\beta_{2}\right)$ yakni sebesar 0,417 membuktikan bahwa variabel perceived ease of use mempunyai hubungan positif pada attitude towards use teknologi SIA atas proses bisnis penggajian karyawan. Apabila perceived ease of use meningkat, maka attitude towards use teknologi SIA penggajian karyawan bagian departure frontliner di PT Garuda Indonesia Station DPS akan meningkat. 
ISSN: 2302-8556

E-Jurnal Akuntansi Universitas Udayana

Vol.24.2.Agustus (2018): 1105-1134

Uji kelayakan model $(\mathrm{F})$ digunakan untuk menguji tingkat pengaruh variabel bebas terhadap variabel terikat secara bersama-sama. Hasil Uji F dalam penelitian ini ditunjukkan pada Tabel 8.

\section{Tabel 8.}

Hasil Uji Kelayakan Model (Uji F)

\begin{tabular}{llcccc}
\hline \multicolumn{1}{c}{ Model } & $\begin{array}{c}\text { Sum of } \\
\text { Squares }\end{array}$ & df & $\begin{array}{c}\text { Mean } \\
\text { Square }\end{array}$ & F & Signifikansi \\
\hline \multirow{2}{*}{1 Regression } & 383,606 & 2 & 191,803 & 21,457 & 0,000 \\
Residual & 581,026 & 65 & 8,939 & & \\
$\quad$ Total & 964,632 & 67 & & & \\
\hline Sumber: Data diolah, 2017 & & & &
\end{tabular}

Tabel 8 menunjukkan nilai $\mathrm{F}$ hitung sebesar 21,457 dengan signifikan $\mathrm{F}$ atau $p$ value sebesar 0,000, dimana nilai Sig. F tersebut lebih kecil dari nilai taraf kritis penelitian 0,05 $(0,000<0,05)$. Berdasarkan hal tersebut, model regresi linear berganda layak untuk digunakan untuk menguji pengaruh variabel bebas pada variabel terikat.

Nilai adjusted $R^{2}$ sebesar 0,379 menunjukkan bahwa 37,9\% attitude towards use teknologi SIA atas proses bisnis penggajian karyawan bagian departure frontliner di PT Garuda Indonesia Station DPS dipengaruhi oleh variabel perceived usefulness dan perceived ease of use, sedangkan sisanya sebesar $62,1 \%$ dijelaskan oleh variabel lain di luar model.

Uji t dilakukan dengan tujuan untuk melihat pengaruh masing-masing variabel bebas secara parsial terhadap variabel terikat. Hasil uji t dapat dilihat dalam Tabel 9.

\section{Tabel 9.}

Hasil Uji Hipotesis (Uji t)

\begin{tabular}{crccc}
\hline No. & \multicolumn{1}{c}{ Variabel } & $\boldsymbol{\beta}$ & $\mathbf{t}_{\text {hitung }}$ & Signifikansi \\
\hline 1. & Perceived Usefulness & 0,437 & 2,750 & 0,008 \\
2. & Perceived Ease of Use & 0,417 & 2,127 & 0,037 \\
\hline \multicolumn{2}{l}{ Sumber: Data diolah, 2017 }
\end{tabular}


Berdasarkan tabel 9, baik variabel perceived usefulness maupun variabel perceived ease of use secara parsial berpengaruh positif terhadap variabel attitude towards use teknologi SIA penggajian. Hasil pengujian hipotesis pertama $\left(\mathrm{H}_{1}\right)$ memperlihatkan bahwa perceived usefulness berpengaruh positif terhadap attitude towards use teknologi SIA atas proses bisnis penggajian. Hasil ini ditunjukkan dengan nilai Sig. t sebesar 0,008. Nilai Sig. t tersebut menunjukkan angka lebih kecil dari taraf kritis penelitian ini $(0,05)$. Berdasarkan hal tersebut, hasil penelitian ini membuktikan bahwa $\mathrm{H}_{1}$ diterima. Hal ini berarti, semakin karyawan merasakan manfaat teknologi SIA penggajian, maka sikap penerimaannya terhadap teknologi tersebut akan meningkat. Hasil ini sesuai dengan teori TAM yang menyebutkan bahwa penerimaan penggunaan teknologi informasi dipengaruhi oleh kemanfaatan yang dirasakan penggunanya.

Berdasarkan hasil analisis karakteristik responden di PT Garuda Indonesia station DPS, dapat dilihat bahwa mayoritas responden berjenis kelamin perempuan sebesar $68 \%$. Hal ini dapat menjadi salah satu faktor pendukung meningkatnya sikap penggunaan teknologi SIA penggajian di PT Garuda Indonesia station DPS, karena pada umumnya perempuan lebih teliti dibandingkan laki-laki. Perempuan lebih suka menggunakan sistem yang bermanfaat dalam meningkatkan ketelitian. Selanjutnya, mayoritas responden berusia antara 21 hingga 25 tahun yaitu sebesar $62 \%$ dimana usia ini tergolong masih muda, sehingga pengetahuan atas manfaat teknologi lebih banyak. Selain itu, rasa ingin tahu dari teknologi terbaru di usia tersebut umumnya besar. Maka 
ISSN: 2302-8556

E-Jurnal Akuntansi Universitas Udayana Vol.24.2.Agustus (2018): 1105-1134

dari itu, teknologi SIA diterima dengan baik. Berdasarkan hasil analisis, terlihat bahwa sebagian besar pendidikan terakhir responden penelitian adalah Sekolah Menengah Atas (SMA) sebesar 60\%, dimana pada tingkat pendidikan SMA umumnya siswa menerima pendidikan teknologi yang intens, dibuktikan dengan adanya mata pelajaran TIK (Teknologi Informasi dan Komunikasi) yang masuk dalam kurikulum sebagian besar SMA. Dalam mata pelajaran TIK banyak diuraikan manfaat dari penggunaan teknologi di berbagai bidang, hal ini dapat menjelaskan bagaimana sikap penggunaan teknologi SIA penggajian meningkat dikalangan responden penelitian. Karakteristik responden yang terakhir dilihat dari lama bekerja di PT Garuda Indonesia station DPS. Sebanyak 67\% responden penelitian bekerja di PT Garuda Indonesia station DPS selama kurang dari 5 tahun. Hal ini mengindikasikan bahwa karyawan lebih mudah diatur dan diberikan pelatihan terkait manfaat penggunaan teknologi SIA penggajian. Daya serap karyawan baru pada umumnya tergolong baik, sehingga sikap penggunaan teknologi SIA penggajian di PT Garuda Indonesia station DPS meningkat.

Hasil ini juga mendukung penelitian yang dilakukan oleh sejumlah peneliti terdahulu seperti penelitian oleh Davis (1989), Szajna (1994), Kurniawan (2013), Fuad Budiman dan Fefri Indra (2013), serta Amadeus (2016). Hasil pengujian hipotesis kedua $\left(\mathrm{H}_{2}\right)$ menunjukkan bahwa perceived ease of use berpengaruh positif terhadap attitude towards use teknologi SIA atas proses bisnis penggajian. Hasil ini ditunjukkan dengan nilai Sig. t sebesar 0,037. Nilai Sig. t tersebut menunjukkan angka lebih kecil dari taraf kritis dalam penelitian ini yaitu 0,05 . Berdasarkan hal tersebut $\mathrm{H}_{2}$ penelitian 
ini diterima, yang membuktikan bahwa semakin karyawan merasa bahwa suatu teknologi SIA penggajian dapat dengan mudah digunakan, maka sikap penerimaannya terhadap teknologi tersebut akan meningkat. Hasil ini sesuai dengan teori TAM yang menyebutkan bahwa penerimaan teknologi informasi dipengaruhi kemudahan yang dirasakan penggunanya.

Berdasarkan hasil analisis karakteristik responden di PT Garuda Indonesia station DPS, responden berjenis kelamin perempuan terhitung sebesar 68\%. Pada umumnya perempuan lebih berhati-hati dibandingkan laki-laki. Oleh sebab itu, pada umumnya perempuan lebih suka menggunakan sistem yang mudah digunakan sehingga dirinya bebas dari masalah selama penggunaan teknologi tersebut. Selanjutnya, mayoritas responden di lokasi penelitian berusia antara 21 hingga 25 tahun yaitu sebesar $62 \%$, dimana pada usia yang masih muda tersebut pada umumnya telah terbiasa menggunakan teknologi. Maka dari itu, sikap penggunaan teknologi sistem informasi akuntansi dapat meningkat. Selanjutnya, berdasarkan hasil analisis, terlihat bahwa sebagian besar pendidikan terakhir responden penelitian adalah SMA (60\% responden). Pada tingkat pendidikan SMA, umumnya siswa menerima pendidikan TIK yang intens. Mata pelajaran tersebut tentunya memberikan kontribusi dalam memudahkan penggunaan teknologi, sehingga teknologi akan dirasa semakin user friendly yang berujung pada meningkatknya sikap penggunaan teknologi termasuk teknologi SIA penggajian. Selanjutnya, sebanyak $67 \%$ responden penelitian bekerja di PT Garuda Indonesia station DPS selama kurang dari 5 tahun. Hal ini mengindikasikan 
ISSN: 2302-8556

E-Jurnal Akuntansi Universitas Udayana Vol.24.2.Agustus (2018): 1105-1134

bahwa karyawan lebih mudah diatur dan diberikan pelatihan yang sifatnya repetitif sehingga penggunaan teknologi SIA penggajian menjadi lebih mudah. Daya serap karyawan baru pada umumnya tergolong baik, sehingga sikap penggunaan teknologi SIA penggajian di PT Garuda Indonesia station DPS meningkat.

Hasil ini turut mendukung hasil penelitian-penelitian sebelumnya yang memperoleh kesimpulan bahwa variabel perceived ease of use berpengaruh terhadap variabel attitude towards use, diantaranya yaitu penelitian Davis tahun 1989, penelitian Szajna (1994), penelitian Budi Santoso (2012), Penelitian David Kurniawan (2013), penelitian Fuad Budiman dan Fefri Indra (2013), serta penelitian Amadeus (2016).

Implikasi penelitian ini terbagi menjadi implikasi teoritis dan praktis. Untuk implikasi teoritis, hasil penelitian ini memberikan tambahan informasi mengenai bagaimana perceived usefulness serta perceived ease of use mempengaruhi attitude towards use teknologi SIA atas proses bisnis penggajian. Terdapat bukti empiris yang diperoleh melalui penelitian ini yang menunjukkan bahwa perceived usefulness dan perceived ease of use berpengaruh positif terhadap attitude towards use teknologi SIA atas proses bisnis penggajian. Hal ini menunjukkan, semakin tinggi tingkat perceived usefulness dan perceived ease of use-nya, maka attitude towards use teknologi SIA penggajiannya akan semakin meningkat. Hal ini didukung dengan teori TAM yang menjelaskan persepsi pengguna dapat menentukan sikap penerimaan penggunaan teknologi. Hal ini juga diperkuat dengan teori TRA yang menjelaskan bahwa perilaku dapat dijelaskan dengan mempertimbangkan kepercayaannya. Sementara itu, untuk 
implikasi praktis, hasil penelitian ini dapat digunakan sebagai pertimbangan karyawan untuk menggunakan teknologi SIA penggajian dalam melakukan proses penggajiannya. Selain itu, hasil penelitian ini dapat menjadi pertimbangan perusahaan untuk mempertahankan dan meningkatkan penggunaan teknologi SIA penggajian.

\section{SIMPULAN}

Berdasarkan analisis dan pembahasan hasil penelitian, maka dapat disimpulkan bahwa perceived usefulness berpengaruh positif terhadap attitude towards use teknologi SIA atas proses bisnis penggajian. Semakin karyawan merasakan manfaat dari suatu teknologi SIA penggajian, maka sikap penerimaannya terhadap teknologi tersebut akan meningkat. Begitu pula dengan perceived ease of use yang juga berpengaruh positif terhadap attitude towards use teknologi SIA atas proses bisnis penggajian. Semakin karyawan merasa bahwa suatu teknologi SIA penggajian mudah digunakan, maka sikap penerimaannya juga akan meningkat.

Beberapa saran yang dapat diberikan dalam penelitian ini pertama ditujukan bagi peneliti selanjutnya yang mengambil lokasi penelitian yang sama, sebaiknya dapat memperluas cakupan responden agar tidak hanya mencakup karyawan bagian Departure Frontliner, sehingga dapat menggambarkan kejadian secara lebih menyeluruh. Selain itu, peneliti selanjutnya dapat mencoba untuk memilih responden yang merupakan pengguna akhir (end-user) dari teknologi SIA penggajian. Hal ini karena keterlibatannya dalam proses penggajian lebih besar, sehingga responden lebih paham terhadap teknologi SIA penggajian tersebut. Bagi pihak PT. Garuda Indonesia 
ISSN: 2302-8556

E-Jurnal Akuntansi Universitas Udayana Vol.24.2.Agustus (2018): 1105-1134

Station DPS diharapkan dapat memberi sosialisasi lebih banyak kepada karyawan bagian Departure Frontliner agar penerimaan terhadap teknologi SIA penggajian terus meningkat. Selanjutnya bagi karyawan bagian Departure Frontliner disarankan untuk menggunakan teknologi SIA penggajian karena teknologi tersebut dapat membantu proses penggajian menjadi lebih baik.

\section{REFERENSI}

Al-eqab, M. dan Adel, D. 2013. The Impact of IT Sophistications on the Perceived Usefulness of Accounting Information Characteristics among Jordanian Listed Companies. Journal of Bussiness and Social Science, 4 (3), pp: 145-155.

Alsarayreh M.N., Jawabreh O.A., Jaradat M.F., dan Alamro S.A. 2011. Technological Impact on Effectiveness of Accounting Information System (AIS) Applied by Aqaba Tourist Hotels. European Journal of Scientific Research, 59(3), pp: 361369.

Armanda, Ribka, 2015. Analisis Faktor Penerimaan dan Penggunaan Teknologi dalam Sistem Informasi Akuntansi dengan Pendekatan TAM. Jurnal Ilmu \& Riset Akuntansi, 4(3), pp: 1-21.

Bodnar, G.H., dan W.S. Hopwood. 2006. Sistem Informasi Akuntansi. Edisi 9. Yogyakarta : Penerbit ANDI.

Budiman, Fuad dan Arza, Fefri Indra. 2013. Pendekatan Technology Acceptance Model dalam Kesuksesan Implementasi Sistem Informasi Manajemen Daerah. Jurnal WRA, 1(1), pp: 87-110.

Bungin, Burhan. 2005. Metodologi Penelitian Kuantitatif, Komunikasi, Ekonomi, dan Kebijakan Publik serta Ilmu-ilmu Sosial Lainnya. Edisi Kedua. Jakarta : Kencana Prenada Media Group.

Davis, F.D. 1989. Perceived Usefulness, Perceived Ease of Use, and Acceptance of Information System Tecnology. MIS Quarterly, 13(3), pp: 319-339. 
Fishbein, Martin, dan Icek Ajzen. 1975. Belief, Attitude, Intention, and Behavior: An Introduction to Theory and Research. Philosophy \& Rhetoric, 10(2), pp: 130132

Gelinas, Oram, dan Wiggins. 1990. Accounting Information Systems. Boston : PWSKENT Publishing Company.

Ghozali, Imam. 2013. Aplikasi Analisis Multivariate dengan Program SPSS 21. Semarang : Badan Penerbit Universitas Diponegoro

Handayani, Rini. 2005. Analisis Faktor-Faktor yang Memengaruhi Minat Pemanfaaan Sistem Informasi dan Penggunaan Sistem Informasi (Studi Empiris pada Perusahaan Manufaktur di Bursa Efek Jakarta). Jurnal Akuntansi dan Keuangan, 9(2), pp: 7687.

Hartono, Jogiyanto. 2007. Sistem Informasi Keprilakuan. Yogyakarta : Badan penerbit C.V ANDI OFFSET.

Ikhsan, Arfan. 2008. Metodologi Penelitian Akuntansi Keperilakuan. Edisi 1. Yogyakarta: Graha Ilmu.

Kezia, R dan Jantje. 2016. Evaluasi Penerapan Sistem Informasi Akuntansi Penggajian untuk Pengendalian Intern pada PT. BPR Danaku Mapan Lestari di Kota Blitung. Jurnal EMBA, 4 (2), pp: 224-235.

Kristiani, Wahyu. 2012. Analisis Pengaruh Efektifitas Teknologi Sistem Informasi Akuntansi Terhadap Kinerja Individual Pegawai PT. Kim Eng Sekuritas Indonesia, Gunadarma University, College of Economic. http://publication.gunadarma.ac.id/bitstream/123456789/5674/1/My\%20Jurn al.pdf. Diunduh tanggal 14, bulan September, tahun 2017.

Kurniawan, David., Semuel, Hatane., dan Japarianto, Edwin. 2013. Analisis Penerimaan Nasabah terhadap Layanan Mobile Banking dengan Menggunakan Pendekatan Technology Acceptance Model dan Theory of Reasoned Action. Jurnal Manajemen Pemasaran Universitas Kristen Petra, 1(1), pp: 1-13 
ISSN: 2302-8556

E-Jurnal Akuntansi Universitas Udayana Vol.24.2.Agustus (2018): 1105-1134

Kustono, Alwan Sri. 2011. Pengaruh Keahlian Pengguna Terhadap Kinerja Sistem Informasi dengan Variabel Intervening Partisipasi, Kecemasan, Kepuasan, Derajat Penerimaan, dan Ketidakpastian Kerja. Jurnal Ilmiah Ekonomi Manajemen dan Kewirausahaan "Optimal”,5 (1), pp: 38-50.

McCoy, Scott, Andrea Everard, dan Brian M. Jones. 2005. An Examination of the Technology Acceptance Model in Uruguay and the US: A Focus on Culture. Journal of Global Information Technology Management, 8(2), pp: 27-45.

Mulyadi. 2014. Sistem Akuntansi. Edisi 3, Cetakan ke-5. Jakarta : Salemba Empat.

Nasution, Fahmi Natigor. 2004. Penggunaan Teknologi Informasi Berdasarkan Aspek Perilaku (Behavioral Aspect). USU digital library, pp: 1-10

Nugraha, Amadeus Vincent Reziario dan Juliarsa, Gede. 2016. Penggunaan Sistem Informasi Akuntansi Berbasis Teknologi Informasi dengan Model TAM pada Hotel di Kabupaten Gianyar. E-Jurnal Akuntansi Universitas Udayana, 17(2), pp: 1196-1225.

Raupeliene, Asta. 2003. Development of A Model For Evaluating The Effectiveness of Accounting Information Systems. Journal of Lithuanian University, pp: 339345 .

Romney, Marshal B dan Paul John Steinbart. 2005. Accounting Information System Buku Dua. Edisi 9. Jakarta : Salemba Empat.

Santoso, Budi. 2012. Pengaruh Perceived Usefulness, Perceived Ease of Use, dan Perceived Enjoyment terhadap Penerimaan Teknologi Informasi (Studi Empiris di Kabupaten Sragen). Jurnal Studi Akuntansi Indonesia, 10(2), pp: 1-15.

Sumistar, Ethik Aprilia. 2011. Pengaruh Minat Pemanfaatan Sistem Informasi dan Penggunaan Sistem Informasi terhadap Kinerja Individu (Studi pada PT. Samator Gas Industri, Diponegoro University, College of Economic. http://eprints.undip.ac.id/26644/1/SKRIPSI_ETHIK_APRILIA_S(r).pdf.

Diunduh tanggal 22, bulan Mei, tahun 2017.

Suseno, B.H. 2009. Analisis Faktor-Faktor yang Mempengaruhi Penerimaan oleh Karyawan PT KAI (persero) terhadap Sistem E-Ticket di Semarang : dengan Menggunakan Pendekatan Techonology Acceptance Model (TAM). Jurnal Jurusan Akuntansi Fakultas Ekonomi Universitas Diponegoro. 
Szajna, B. 1994. Software Evaluation and Choice : Predictive Validation of The Technology Acceptance Instrument. MIS Quarterly, 18(3), pp: 319-324.

Thompson, R.L., Higgins, christopher A., dan Howwel, Jane M. 1994. Influence of Experience on Personal Computer Utilization: Testing A Conceptual Model. Journal of Management Information Systems. 11(1), pp: 167-187. 